\title{
Maternal Hyperthyroidism and Developing Thyroid Cancer: What is the Next?
}

\author{
Ahmed R.G* \\ Division of Anatomy and Embryology, Zoology Department, Faculty of Science, Beni-Suef University, Beni- \\ Suef, Egypt
}

*Corresponding Author: Ahmed R.G, Division of Anatomy and Embryology, Zoology Department, Faculty of Science, Beni-Suef University, Beni-Suef, Egypt, Email: ahmedragab08@gmail.com

\section{COMMENTARY}

Optimal actions in the maternal thyroid hormones (THs; 3,5,3'-triiodothyronine (T3) and thyroxine (T4)) during pregnancy are central to a normal fetal and neonatal consequence (Elbakry et al., 2010; Ahmed, 2011, 2012a,b, 2013, 2014, 2015a-c, 2016a-d, 2017a-v, 2018a-u; Ahmed and Ahmed, 2012; Ahmed et al., 2008; 2010; 2012; 2013a,b, 2014, 2015a,b, 2018a,b; Ahmed and Incerpi, 2013; Van Hercket al., 2013; Ahmed and El-Gareib, 2014,Incerpi et al., 2014; Candelotti et al., 2015; De Vito et al., 2015; El-Ghareeb et al., 2016; Ahmed and ElGareib, 2017). On the other hand, a controversial association between THs and cancer was observed. Some authors postulating that hyperthyroidism can induce cancer development and progression (Gabriele et al., 2003; Furumoto et al., 2005; Davis et al., 2006; Nishida et al., 2008; Kress et al., 2010), although others have stated a tumor inhibition action of THs (Ruiz-Llorente et al., 2011; Manka et al., 2018). Galdiero et al. (2016) reported that about $90 \%$ of the endocrine malignancies are a thyroid cancer. A toxic nodular goiter (TNG) can increase the risk of metastatic follicular thyroid carcinoma (FTC) (Sahin et al., 2005). It appears that the prediction of metastatic follicular carcinoma does not fluctuate with the attendance or lacking hyperthyroidism (Tsuchiya et al., 1987; Paul and Sisson, 1990; Lin et al., 2004; Giovanella et al., 2010). As well, Cakir et al. (2007) suggested that the prevalence of thyroid carcinoma was lower in subjects with Graves' disease than in subjects with toxic adenoma (TA) or toxic multi nodular goiter (TMG). Several investigators reported that Graves' disease (20-25\%) is the utmost communal cause of hyperthyroidism and the frequency of thyroid nodules (Pacini et al., 1998; Kraimps et al., 2000; Taneri et al., 2005). Indeed, cancer related to Graves' disease appears to be more destructive than those linked to multi nodular toxic goiter (MTG) or uni nodular toxic goiter (UTG) (Cappelli et al., 2006). In addition, Wong et al. (2003) observed that thyrotoxicosis in women was associated with Hurthle cell carcinoma of the thyroid (a rare type of thyroid neoplasm).

More importantly, develop thyroid cancer in patients with Graves' and thyroid nodules were more severe than in patients with diffuse goiter (Pazaitou- Panayiotou et al., 2012). The possibility of Graves' disease and development of thyroid cancer, mainly of papillary carcinoma can be attributed to the presence of thyroid auto antibodies (Filetti et al., 1988; Belfiore et al., 1990; Pellegriti et al., 1998; Gagliano et al., 2016).

Finally, it is worth pronouncing that maternal hyperthyroidism or thyrotoxicosis may increase the rate of development and progression of thyroid carcinoma and thyroid nodules. The disorders in the actions of the maternal thyroid gland (thyroid carcinoma or nodules) may disrupt the fetal and neonatal development and increase the possibility of mortality and morbidity. These disturbances may be depending on a family history of thyroid cancer, multiple endocrine neoplasia syndromes, a rapid growth of a nodule, and cervical lymphadenopathy. Thus, the incidence of a nodule in a hyper thyroidism or thyrotoxicosis should be carefully assessed to eliminate the attendance of malignancy. Additional studies are necessary to study the clinical and pathological features of materno fetal thyrotoxicosis and thyroid micro carcinoma (distinguish aggressive lesions from benign adenomas). It is important to study the prediction of non-metastatic hyperthyroidism with the follicular thyroid carcinoma. Additionally, every suspicious nodule related to hyperthyroidism should be appraised importantly. 


\section{REFERENCES}

[1] Ahmed, O.M., Abd El-Tawab, S.M., Ahmed, R.G., 2010. Effects of experimentally induced maternal hypothyroidism and hyper thyroidism on the development of rat offspring: I- The development of the thyroid hormones-neuro transmitters and adenosinergic system interactions. Int. J. Dev. Neurosci. 28, 437-454.

[2] Ahmed, O.M., Ahmed, R.G., 2012. Hypo thyroidism. In A New Look at Hypothyroidism. Dr. D. Springer (Ed.), ISBN: 978-953-51-0020-1), In Tech Open Access Publisher, Chapter 1, pp. 120.

[3] Ahmed, O.M., Ahmed, R.G., El-Gareib, A.W., El-Bakry, A.M., Abd El-Tawab, S.M., 2012. Effects of experimentally induced maternal hypothyroidism and hyperthyroidism on the development of rat offspring: II-The developmental pattern of neurons in relation to oxidative stress and antioxidant defense system. Int. J. Dev. Neurosci. 30, 517-537.

[4] Ahmed, O.M., El-Gareib, A.W., El-bakry, A.M., Abd El-Tawab, S.M., Ahmed, R.G., 2008. Thyroid hormones states and brain development interactions. Int. J. Dev. Neurosci. 26(2), 147-209. Review.

[5] Ahmed, R.G., 2011. Perinatal 2, 3, 7, 8-tetra chloro di benzo- p-dioxin exposure alters developmental neuroendocrine system. Food Chem. Toxicology, 49, 1276-1284.

[6] Ahmed, R.G., 2012a. Maternal-new born thyroid dysfunction. In the Developmental Neuro endocrinology, pp.1-369. Ed R.G. Ahmed. Germany: LAP LAMBERT Academic Publishing GmbH \& Co KG.

[7] Ahmed, R.G., 2012b. Maternal-fetal thyroid interactions, Thyroid Hormone, Dr. N.K. Agrawal (Ed.), ISBN: 978-953-51-0678-4, In Tech Open Access Publisher, Chapter 5, pp. 125-156.

[8] Ahmed, R.G., 2013. Early weaning PCB 95 exposure alters the neonatal endocrine system: thyroid adipokine dysfunction. J. Endocrinol. 219 (3), 205-215.

[9] Ahmed, R.G., 2014. Editorial: Do PCBs modify the thyroid-adipokine axis during development? Annals Thyroid Res. 1(1), 11-12.

[10] Ahmed, R.G., 2015a. Chapter 1: Hypothyroidism and brain development. In advances in hypo thyroidism treatment. Avid Science Borsigstr. 9, 10115 Berlin, Berlin, Germany. Avid Science Publications level 6, Melange Towers, Wing a, Hitec City, Hyderabad, Telangana, India. pp. 140.

[11] Ahmed, R.G., 2015b. Hypothyroidism and brain developmental players. Thyroid Research J. 8(2), $1-12$.

[12] Ahmed, R.G., 2015c. Editorials and Commentary: Maternofetal thyroid action and brain development. J. of Advances in Biology; 7(1), 1207-1213.

[13] Ahmed, R.G., 2016a. Gestational dexamethasone alters fetal neuroendocrine axis. Toxicology Letters, 258, 46-54.

[14] Ahmed, R.G., 2016b. Neonatal polychlorinated biphenyls-induced endocrine dysfunction. Ann. Thyroid. Res. 2 (1), 34-35.

[15] Ahmed, R.G., 2016c. Maternal iodine deficiency and brain disorders. Endocrinol. Metab.Syndr.5, 223. http://dx.doi.Org/ 10. 4172 12161-1017. 1000223.

[16] Ahmed, R.G., 2016d. Maternal bisphenol A alters fetal endocrine system: Thyroid adipokine dysfunction. Food Chem. Toxicology, 95, 168174.

[17] Ahmed, R.G., 2017a. Developmental thyroid diseases and GABAergic dysfunction. EC Neurology 8.1, 02-04.

[18] Ahmed, R.G., 2017b. Hyperthyroidism and developmental dysfunction. Arch Med. 9, 4.

[19] Ahmed, R.G., 2017c. Anti-thyroid drugs may be at higher risk for perinatal thyroid disease. EC Pharmacology and Toxicology 4.4, 140142.

[20] Ahmed, R.G., 2017d. Perinatal hypothyroidism and cytoskeleton dysfunction. Endocrinol Metab Syndr 6, 271. doi: 10.4172/2161-1017. 1000271

[21] Ahmed, R.G., 2017e. Developmental thyroid diseases and monoaminergic dysfunction. Advances in Applied Science Research 8(3), 01-10.

[22] Ahmed, R.G., 2017f. Hypothyroidism and brain development. J. Anim Res Nutr. 2(2), 13.

[23] Ahmed, R.G., 2017g. Antiepileptic drugs and developmental neuroendocrine dysfunction: Every why has A Where fore. Arch Med 9(6), 2.

[24] Ahmed, R.G., 2017h. Gestational pro oxidantantioxidant imbalance may be at higher risk for postpartum thyroid disease. Endocrinol Metab Syndr 6, 279. doi:10.4172/2161-1017.1000279.

[25] Ahmed, R.G., 2017i. Synergistic actions of thyroid-adipokines axis during development. Endocrinol Metab Syndr 6, 280. doi: 10.4172/ 2161-1017.1000280.

[26] Ahmed, R.G., 2017j. Thyroid-insulin dysfunction during development. International Journal of Research Studies in Zoology 3(4), 73-75. DOI: http://dx.doi.org/10.20431/2454-941X.0304010.

[27] Ahmed, R.G., 2017k. Developmental thyroid diseases and cholinergic imbalance. International Journal of Research Studies in Zoology 3(4), 7072.DOI:http://dx.doi.org/10.20431/2454941X.0304 009.

[28] Ahmed, R.G., 20171. Thyroid diseases and developmental adenosinergic imbalance. Int $\mathbf{J}$ ClinEndocrinol 1(2), 053-055. 
[29] Ahmed, R.G., 2017m. Maternal anticancer drugs and fetal neuroendocrine dysfunction in experimental animals. Endocrinol MetabSyndr 6, 281.doi:10.4172/2161-1017.1000281.

[30] Ahmed, R.G., 2017n. Letter: Gestational dexamethasone may be at higher risk for thyroid disease developing peripartum. Open Journal of Biomedical \& Life Sciences (Ojbili) 3(2), 01-06.

[31] Ahmed, R.G., 2017o. Deiodinases and developmental hypothyroidism. EC Nutrition 11.5, 183-185.

[32] Ahmed, R.G., 2017p. Maternofetal thyroid hormones and risk of diabetes. Int. J. of Res. Studies in Medical and Health Sciences 2(10), 18-21.

[33] Ahmed, R.G., 2017r. Association between hypothyroidism and renal dysfunctions. International Journal of Research Studies in Medical and Health Sciences 2(11), 1-4.

[34] Ahmed, R.G., 2017s.Maternal hypothyroidism and lung dysfunction. International Journal of Research Studies in Medical and Health Sciences 2(11), 8-11.

[35] Ahmed, R.G., 2017t. Endocrine disruptors; possible mechanisms for inducing developmental disorders. International journal of basic science in medicine (IJBSM) 2(4), 157-160.

[36] Ahmed, R.G., 2017u.Maternal thyroid hormones trajectories and neonatal behavioral disorders. ARC Journal of Diabetes and Endocrinology 3(2), 18-21.

[37] Ahmed, R.G., 2017v.Maternal thyroid dysfunction and neonatal cardiac disorders. Insights Biol Med. 1, 092-096.

[38] Ahmed, R.G., 2018a. Maternal hypothyroidism and neonatal testicular dysfunction. International Journal of Research Studies in Medical and Health Sciences 3(1), 8-12.

[39] Ahmed, R.G., 2018b. Maternal hypothyroidism and neonatal depression: Current perspective. International Journal of Research Studies in Zoology 4(1), 6-10. DOI: http://dx.doi.org/ 10.20431/2454-941X.0401002.

[40] Ahmed, R.G., 2018c. Non-genomic actions of thyroid hormones during development. App ClinPharmacolToxicol: ACPT-108. DOI: 10. 29011/ACPT-109. 100008.

[41] Ahmed, R.G., 2018d. Maternal thyroid function and placental hemodynamics. ARC Journal of Animal and Veterinary Sciences 4(1), 9-13. DOI: http://dx.doi.org/10.20431/2455-2518. 0401002.

[42] Ahmed, R.G., 2018e.Interactions between thyroid and growth factors during development. ARC Journal of Diabetes and Endocrinology 4(1), 1-4. DOI: http://dx.doi.org/ 10.20431/ 24555983.0401001.

[43] Ahmed, R.G., 2018f. Maternal thyroid hormones and neonatal appetite. ARC Journal of Nutrition and Growth 4(1), 18-22. DOI: http://dx.doi.org/ 10.20431/2455-2550.0401005.

[44] Ahmed, R.G., 2018g. Genomic actions of thyroid hormones during development. ARC Journal of Diabetes and Endocrinology 4(1), 58. DOI: http://dx.doi.org/10.20431/2455-5983. 0401002.

[45] Ahmed, R.G., 2018h. Dysfunction of maternal thyroid hormones and psychiatric symptoms. American Research Journal of Endocrinology. 2(1), 1-6.

[46] Ahmed, R.G., 2018i. Is there a connection between maternal hypothyroidism and developing autism spectrum disorders? ARC Journal of Neuroscience 3(1), 5-8. DOI: http://dx.doi.org/ 10.20431/2456057X.0301002.

[47] Ahmed, R.G., 2018j. Maternal thyroid dysfunctions and neonatal bone mal development. American Research Journal of Endocrinology (in press) Xx-xxx.

[48] Ahmed, R.G., 2018k. Maternal thyroid disorders and risk of neonatal seizure: Current perspective. ARC Journal of Neuroscience 3(1), 21-25. DOI: http://dx.doi.org/10.20431/2456-057X.0301004

[49] Ahmed, R.G., 20181. Gestational dioxin acts as developing neuroendocrine-disruptor. EC Pharmacology and Toxicology 6.3, 96-100.

[50] Ahmed, R.G., 2018m. Maternal thyroid dysfunction and risk of neonatal stroke. ARC Journal of Animal and Veterinary Sciences 4(1), 22-26. DOI: http://dx.doi.org/10.20431 /24552518. 0401004

[51] Ahmed, R.G., 2018n. Maternal thyroid disorders and developing skin dysfunctions. ARC Journal of Dermatology 3(1), 13-17. DOI: http://dx.doi.org/10.20431/2456-0022.0301005

[52] Ahmed, R.G., 2018o. Maternal hypothyroidismmilk ejections: What is the link? ARC Journal of Nutrition and Growth 4(1), 29-33. DOI: http://dx.doi.org/ 10.20431/2455-2550.0401007

[53] Ahmed, R.G., 2018p. Does maternal antepartum hypothyroidism cause fetal and neonatal hyponatremia? ARC Journal of Diabetes and Endocrinology 4(1), Xx-Xxx. DOI: http://dx.doi.org/10.20431/2455-5983. 0401004

[54] Ahmed, R.G., 2018q. Maternal hypothyroidism and rheumatoid arthritis. International Journal of Research Studies in Medical and Health Sciences Volume 3(2), 1-5.

[55] Ahmed, R.G., 2018r. Developmental thyroid and skeletal muscle dysfunction.ARC Journal of Diabetes and Endocrinology 4(1), xx-xxx. DOI: http://dx.doi.org/10.20431/2455-5983. 0401003.

[56] Ahmed, R.G., 2018s.Hyperthyroidism and renal disorders. ARC Journal of Animal and Veterinary Sciences 4(2), 1-5. DOI: http://dx.doi.org /10. 20431/2455-2518.0402001 
[57] Ahmed, R.G., 2018t.Maternal hypothyroidism and developing hyperhomocysteinemia.ARC Journal of Nutrition and Growth 4(2), xx-xxx. DOI: http://dx.doi.org/10.20431/2455-2550. 0402002

[58] Ahmed, R.G., 2018u. Maternal hyperthyroidism and neonatal testicular dysfunction.ARC Journal of Urology 3(1), xx-xxx. DOI: http://dx.doi.org /10.20431/2456-060X. 0301002

[59] Ahmed, R.G., Abdel-Latif, M., Ahmed F., 2015a. Protective effects of GM-CSF in experimental neonatal hypothyroidism. International Immuno pharmacology 29, 538-543.

[60] Ahmed, R.G., Abdel-Latif, M., Mahdi, E., ElNesr, K., 2015b. Immune stimulation improves endocrine and neural fetal outcomes in a model of maternofetal thyrotoxicosis. Int. Immuno pharmacol. 29, 714-721.

[61] Ahmed, R.G., Davis, P.J., Davis, F.B., De Vito, P., Farias, R.N., Luly, P., Pedersen, J.Z., Incerpi, S., 2013a. Nongenomic actions of thyroid hormones: from basic research to clinical applications. An update. Immunology, Endocrine \& Metabolic Agents in Medicinal Chemistry, 13(1), 46-59.

[62] Ahmed, R.G., El-Gareib, A.W. 2014.Lactating PTU exposure: I- Alters thyroid-neural axis in neonatal cerebellum. Eur. J. of Biol. and Medical Sci. Res. 2(1), 1-16.

[63] Ahmed, R.G., El-Gareib, A.W., 2017.Maternal carbamazepine alters fetal neuroendocrinecytokines axis. Toxicology 382, 59-66.

[64] Ahmed, R.G., El-Gareib, A.W., Incerpi, S., 2014. Lactating PTU exposure: II- Alter's thyroid-axis and prooxidant-antioxidant balance in neonatal cerebellum. Int. Res. J. of Natural Sciences 2(1), 1-20.

[65] Ahmed, R.G., El-Gareib, A.W., Shaker, H.M., 2018a.Gestational 3,3', 4, 4', 5-pentachlorobiphenyl (PCB 126) exposure disrupts feto placental unit: Fetal thyroid-cytokines dysfunction. Life Sciences 192, 213-220.

[66] Ahmed, R.G., Incerpi, S., 2013. Gestational doxorubicin alters fetal thyroid-brain axis. Int. J. Devl. Neuroscience 31, 96-104.

[67] Ahmed, R.G., Incerpi, S., Ahmed, F., Gaber, A., 2013b. The developmental and physiological interactions between free radicals and antioxidant: Effect of environmental pollutants. J. of Natural Sci. Res. 3(13), 74-110.

[68] Ahmed, R.G., Walaa G.H., Asmaa F.S., 2018b.Suppressive effects of neonatal bisphenol A on the neuroendocrine system. Toxicology and Industrial Health Journal (in press).

[69] Belfiore, A., Garofalo, M., Giuffrida, D., 1990. Increased aggressiveness of thyroid cancer in patients with Graves' disease.J ClinEndocrinolMetab 70, 830.
[70] Cakir, M., Arici, C., Alakus, H., Altunbas, H., Balci, M.K., Karayalcin, U., 2007. Incidental thyroid carcinoma in thyrotoxic patients treated by surgery. Horm Res. 67(2), 96-9.

[71] Candelotti, E., De Vito, P., Ahmed, R.G., Luly, P., Davis, P.J., Pedersen, J.Z., Lin, H-Y., Incerpi, I., 2015. Thyroid hormones crosstalk with growth factors: Old facts and new hypotheses. Immun., Endoc. \& Metab. Agents in Med. Chem., 15, 7185.

[72] Cappelli, C., Braga, M., De Martino, E., Castellano, M., Gandossi, E., Agosti, B., Cumetti, D., Pirola, I., Mattanza, C., Cherubini, L., Rosei, E.A., 2006. Outcome of patients surgically treated for various forms of hyperthyroidism with differentiated thyroid cancer: experience at an endocrine center in Italy. Surg Today 36(2), 125-30.

[73] Davis, F.B., Tang, H.-Y., Shih, A., Keating, T., Lansing, L., Hercbergs, A., Fenstermaker, R.A., Mousa, A., Mousa, S.A., Davis, P.J., Lin, H.-Y., 2006. Acting via a cell surface receptor, thyroid hormone is a growth factor for glioma cells, Canc. Res. 66, 7270-7275.

[74] De Vito, P., Candelotti, E., Ahmed, R.G., Luly, P., Davis, P.J., Incerpi, S., Pedersen, J.Z., 2015.Role of thyroid hormones in insulin resistance and diabetes. Immun., Endoc. \& Metab. Agents in Med. Chem., 15, 86-93.

[75] El-bakry, A.M., El-Ghareeb, A.W., Ahmed, R.G., 2010.Comparative study of the effects of experimentally-induced hypothyroidism and hyperthyroidism in some brain regions in albino rats. Int. J. Dev. Neurosci. 28, 371-389.

[76] El-Ghareeb, A.A., El-Bakry, A.M., Ahmed, R.G., Gaber, A., 2016.Effects of zinc supplementation in neonatal hypothyroidism and cerebellar distortion induced by maternal carbimazole. Asian Journal of Applied Sciences 4(04), 1030-1040.

[77] Filetti, S., Belfiore, A., Amir, S., 1988. The role of thyroid-stimulating antibodies of Graves' disease in differentiated thyroid cancer. N Engl J Med 318, 753.

[78] Furumoto, H., Ying, H., Chandramouli, G.V.R., Zhao, L., Walker, R.L., Meltzer, P.S., Willingham, M.C., Cheng, S.-Y., 2005. An un liganded thyroid hormone beta receptor activates the cyclin D1/cyclin-dependent kinase/retinoblastoma/E2F pathway and induces pituitary tumor igenesis, Mol. Cell Biol. 25, 124-135.

[79] Gabriele, R.,Letizia, C., Borghese, M., De Toma, G., Celi, M., Izzo, L., Cavallaro, A., 2003. Thyroid cancer in patients with hyperthyroidism. Horm Res. 60, 79-83.

[80] Gagliano, E., Sturniolo, G., Querci, A., Milone, A., Paparo, D., 2016. Concurrent hyperthyroidism and papillary thyroid cancer.J Health Educ Res Dev 4, 203. 
[81] Galdiero, M.R., Varricchi, G., Marone, G., 2016. The immune network in thyroid cancer. Oncoimmunol. e1168556.

[82] Giovanella, L., Fasolini, F., Suriano, S., Mazzucchelli, L., 2010. Hyper functioning solid/ trabecular follicular carcinoma of the thyroid gland. Journal of Oncology 1-4.

[83] Incerpi, S., Hsieh, M-T., Lin, H-Y., Cheng, G-Y., De Vito, P., Fiore, A.M., Ahmed, R.G., Salvia, R., Candelotti, E., Leone, S., Luly, P., Pedersen, J.Z., Davis, F.B., Davis, P.J., 2014. Thyroid hormone inhibition in L6 myoblasts of IGF-I-mediated glucose uptake and proliferation: new roles for integrin $\alpha v \beta 3$. Am. J. Physiol. Cell Physiol. 307, C150-C161.

[84] Kraimps, J.L., Bouin-pineau, M.H., Mathonnet, M., De Calan, L., Ronceray, J., Visset, J., Marechaud, R., Barbier, J., 2000. Multicentre study of thyroid nodules in patients with Graves' disease. Br J Surg. 87, 1111-1113.

[85] Kress, E., Skah, S., Sirakov, M., Nadjar, J., Gadot, N., Scoazec, J.-Y., Samarut, J., Plateroti, M., 2010. Cooperation between the thyroid hormone receptor TRalpha1 and the WNT pathway in the induction of intestinal tumorigenesis, Gastroenterology 138, $1863-1874$

[86] Lin, J.-D., Chao, T.-C., Hsueh, C., 2004. Follicular thyroid carcinomas with lung metastases: a 23-year retrospective study. Endocrine J. 51(2), 219-225.

[87] Manka, P., Coombes, J.D., Boosman, R., Gauthier, K., Papa, S., Syn, W.K., 2018. Thyroid hormone in the regulation of hepatocellular carcinoma and its Microenvironment. Cancer Letters 419, 175-186.

[88] Nishida, A.T.,Hirano, S., Asato, R.,Tanaka, S., Kitani, Y., Honda, N., Fujiki, N., Miyata, K., Fukushima, H., Ito, J., 2008. Multifocal hyper functioning thyroid carcinoma without metastases. Auris Nasus Larynx. 35(3), 432-6.

[89] Pacini, F., Elisei, R., Dicoscio, G.C., Anelli, S., Macchia, E., Concetti, R., Miccoli, P., Arganini, M., Pinchera, A., 1998. Thyroid carcinoma in thyrotoxic patients treated by surgery. J Endocrinol Invest. 11, 107-112.
[90] Paul, S.J., Sisson. J.C., 1990. Thyrotoxicosis caused by thyroid cancer. Endocrinology and Metabolism Clinics of North America 19(3), 593-612.

[91] Pazaitou-Panayiotou, K.,Michalakis, K., Paschke, R.,2012. Thyroid cancer in patients with hyperthyroidism. Horm Metab Res. 44(4), 255-62.

[92] Pellegriti, G., Belfiore, A., Giuffrida, D., Lupo, L., Vigneri, R., 1998. Outcome of differentiated thyroid cancer in Graves' patients. J ClinEndocrinolMetab 83, 2805

[93] Ruiz-Llorente, L., Martínez-Iglesias, O., GarcíaSilva, S., Tenbaum, S., Regadera, J., Aranda, A., 2011.The thyroid hormone receptors as tumor suppressors, Horm. Mol. Biol. Clin. Invest. 5, 7989.

[94] Sahin, M., Guvener, N.D., Ozer, F., Sengul, A., Ertugrul, D., Tutuncu, N.B., 2005. Thyroid cancer in hyperthyroidism: incidence rates and value of ultrasound-guided fine-needle aspiration biopsy in this patient group. J Endocrinol Invest. 28(9), 8158.

[95] Taneri, F., Kurukahvecioglu, O., Ege, B., Yilmaz, U., Tekin, E.H., Cifter, C., Onuk, E., 2005. Clinical presentation and treatment of hyperthyroidism associated with thyroid cancer. Endocrine Regulations 39, 91-96.

[96] Tsuchiya, A., Nemoto, T., Nomizu, T., Sato, H., Watanabe, I., Abe, R., 1987. Follicular carcinoma in an autonomously functioning thyroid nodule. Gan no Rinsho, 33(1), 65-69.

[97] Van Herck, S.L.J., Geysens, S., Bald, E., Chwatko, G., Delezie, E., Dianati, E., Ahmed, R.G., Darras, V.M., 2013. Maternal transfer of methimazole and effects on thyroid hormone availability in embryonic tissues. Endocrinol. 218, 105-115

[98] Wong, C.P., AuYong, T.K., Tong, C.M., 2003. Thyrotoxicosis: a rare presenting symptom of Hurthle cell carcinoma of the thyroid. ClinNucl Med. 28(10), 803-6.

Citation: Ahmed R.G. Maternal Hyperthyroidism and Developing Thyroid Cancer: What is the Next?. ARC Journal of Cancer Science 2018; 4(1):9-13. DOI: http://dx.doi.org/10.20431/2455-6009.0401003

Copyright: (C) 2018 Authors. This is an open-access article distributed under the terms of the Creative Commons Attribution License, which permits unrestricted use, distribution, and reproduction in any medium, provided the original author and source are credited. 